\begin{tabular}{|c|c|}
\hline \multicolumn{2}{|c|}{ PublisherInfo } \\
\hline PublisherName & Palgrave Macmillan UK \\
\hline PublisherLocation & London \\
\hline PublisherImprintName & Palgrave Macmillan \\
\hline
\end{tabular}

\title{
Revisions to quarterly GDP growth and its components
}

\begin{tabular}{||l|l|l||}
\hline \multicolumn{2}{|c|}{ ArticleInfo } \\
\hline \hline ArticleDOI & $:$ & $10.1057 /$ palgrave.elmr.1410170 \\
\hline \hline ArticleCategory & $:$ & Feature \\
\hline \hline ArticleFirstPage & $:$ & 28 \\
\hline \hline ArticleLastPage & $:$ & 35 \\
\hline \hline & $:$ & RegistrationDate $:$ 2007-11-16 \\
ArticleHistory & $:$ & OnlineDate $\quad: 2007-11-16$ \\
\hline \hline ArticleCopyright & $:$ & Crown copyright2007 \\
\hline \hline
\end{tabular}




\section{Presents results of the latest analysis for different stages of the production process and assesses reliability of initial estimates.}

This article presents the results of the latest revisions analysis of gross domestic product (GDP), updating and developing the previous article, Robinson and Obuwa (2006) published in December 2006. Revisions to the estimates of quarterly GDP are analysed at different stages of the production process, and the reliability of initial estimates over two different time periods is assessed. An analysis of revisions to quarterly growth rates for the main components of the expenditure, production and income measures of GDP is also presented. More detailed analysis of the components can be found in the appendices to this article on the National Statistics website at www.statistics.gov.uk/cci/ article.asp? $\mathrm{id}=1888$

Misc

The Full Text of this article can be found on the National Statistics website (http://www.statistics.gov.uk/elmr/11_07/downloads/elmr_nov07_meader.pdf). 